\title{
The diversity and vegetation structure based on growth levels at an urban green campus in Pekanbaru City, Indonesia
}

\author{
DARMAWATI ${ }^{1, \vartheta}$, ARAS MULYADI ${ }^{2}$, SUWONDO $^{1}$, SYAFRI HARTO ${ }^{3}$ \\ ${ }^{1}$ Biology Education Program, Faculty of Teacher Training and Education, Universitas Riau. Jl. H.R. Subrantas Km 12.5, Kampus Bina Widya, Pekanbaru \\ 28293, Riau, Indonesia. Tel./fax.: +62-761-63279, •email: darmawati@lecturer.unri.ac.id \\ ${ }^{2}$ Doctoral Program in Environmental Science, Universitas Riau. Jl. H.R. Subrantas Km 12.5, Kampus Bina Widya, Pekanbaru 28293, Riau, Indonesia \\ ${ }^{3}$ Faculty of Social and Political Sciences, Universitas Riau. Jl. H.R. Subrantas Km 12.5, Kampus Bina Widya, Pekanbaru 28293, Riau, Indonesia
}

Manuscript received: 1 August 2021. Revision accepted: 28 October 2021.

\begin{abstract}
Darmawati, Mulyadi A, Suwondo, Harto S. 2021. The diversity and vegetation structure based on growth levels at an urban green campus in Pekanbaru City, Indonesia. Biodiversitas 22: 5123-5132. The Bina Widya campus of the University of Riau, Pekanbaru, Indonesia has the green open space (GOS) in its area and there are many species of vegetation. In a green open space, variables like diversity and vegetation structure must be considered based on growth levels, this study intended to determine the composition, structure, and diversity of vegetation. The results showed that there were 33 species of trees, 29 species of poles, 16 species of saplings, and 8 species of seedlings from 44 species belonging to 22 families. There were 874 individuals which consisted of 534 trees, 207 poles, 87 saplings, and 46 seedlings. The most common species found was Swietenia macrophylla King (Meliaceae) with 289 individuals. The highest Important Value Index of vegetation species at each growth level was the tree of Alstonia scholaris (L) R.Br (300\%, location IX), the pole of Hibiscus tiliaceus L. (300\%, location VII), saplings of Vitex pinnata L. (300\%, location IV), and S. macrophylla King (300\%, locations I), seedlings of S. macrophylla King (300\%, location I), and Garcinia mangostana L (300\%, location IX). We did not find vegetation species at the levels of sapling or seedling in locations of II, III, V, VI, and VIII. It is necessary to replant the vegetation. The highest Species Diversity Index ( $\left.\mathrm{H}^{\prime}\right)$ at location $\mathrm{X}$ was trees (2.34), poles (2.28), saplings (1.77), and seedlings (1.17). The average H' vegetation at Bina Widya Campus UNRI was 2.44 (medium). Vegetation on the Bina Widya Campus is fairly steady in terms of delivering advantages for human environmental services.
\end{abstract}

Keywords: Campus, green open space, growth level, important value index, species diversity index

\section{INTRODUCTION}

A sustainable campus must have a healthy campus environment by reducing energy and natural resource consumption, waste production, environmental management, and upholding social justice such as human rights and environmental benefits, whose overall value must be represented at the community, city, and national levels (Velazquez et al. 2006; Alshuwaikhat et al. 2008). The Stockholm Declaration in 1972 has opened the world's eyes to the dependence between humans and the environment, then bringing several ways to create a sustainable environment (Alshuwaikhat et al. 2008). The involvement of universities in improving environmental conditions is realized through the concept of a sustainable campus. The campuses should be promoted as an environmental model for sustainable development (Scholl et al. 2015). The Green Campus (GC) initiative is one of the sustainable campus concepts aimed towards the university's environment. Green Campus is a concept to build environmentally friendly sustainable living practices in educational institutions around the world (UI GreenMetric 2020a). The GC program is basically motivated by the problems, that the campus environment is expected to be a comfortable, clean, shady (greeny), beautiful, and healthy place to gain knowledge. The campus environment is also an inseparable part of the urban ecosystem (Tudorie et al. 2020) which applies environmentally friendly principles (Speake et al. 2013). The GC program aims to increase awareness and concern for the campus community as a collection of scientific communities to participate and be responsible for reducing environmental problems such as global warming (UI GreenMetric 2020a).

University of Riau (UNRI) is one of the state universities in Indonesia. The main campus is called the Bina Widya Campus, which has an area of 345.617 ha, it has been functioning since 1983. In implementing the 'tri dharma' of higher education, UNRI conducts education, research, and community service, and is assisted by the Center for Environmental Studies (CES). One of the UNRI-CES work programs is to create a GC environment by integrating the concept of sustainable development based on the mandate in Indonesia Law No. 32 of 2009 concerning Environmental Protection and Management into the policies, management, and activities of higher education (Pusat Studi Lingkungan Hidup 2019). In 2020, UNRI was ranked 35th at the National University of Indonesia (UI) GreenMetric (UI GreenMetric 2020b), an institution established by UI to assess the university's actions towards reforestation and environmental sustainability in the world. UNRI's actions for campus reforestation are shown through regular tree planting activities every single year. The GC is a campus 
environment surrounding by green trees, which is known as Green Open Space (GOS).

The green open space provides many functions such as bioecological (physical) functions, which are part of the air circulation system (city lungs), oxygen producer (Jones 2018; Rózová et al. 2020), microclimate regulator (Zölch et al. 2016), as shade (Bagheri et al. 2017), rainwater absorber, air and water circulation system, (Zhang et al. 2015), animal habitat provider (Gulwadi et al. 2019; Iskandar and Iskandar 2016), absorbent (processing) of air, water and soil, pollutants, windbreaks, suitable places to absorb heat, reduce noise from the surrounding streets, reduce dust (Basrowi et al. 2018; Ives et al. 2016; Sivarajah et al. 2018), socio-economic (productive) or become foodstuffs (Herdiansyah 2020), and cultural functions that are able to describe local cultural expressions, communication media for city residents, places of recreation, places of education and research (Hanan 2013). The GOS function can be used to define local cultural expressions such as constructing a city image based on regional characteristics, such as planting Oncosperma tigillarium (Jack) Ridl, in Riau the plant is called 'Nibung'. The existence of a Science Park and Butterfly Garden on the Bina Widya campus is as a means of communication and as a natural laboratory for practicum and experimental research.

According to the regulation of the Indonesia Minister of Home Affairs No. 1 of 2007 about the arrangement of GOS in urban areas, one of the benefits of GOS is as an educational facility or as an open learning space, a place to meet and socialize (Shan 2014; Wolsink 2016). Green Open Space also has a supporting function of urban ecosystems (Tudorie et al. 2020), aesthetic, and ecological functions (Podhrazka et al. 2021). Aesthetic functions can improve comfort and enhance the city environment on a local (residential) and macro (city landscape as a whole) scale (Purnomohadi 2006). Green Open Space in the campus could be in the form of an urban forest that functions as the protection and preservation of germplasm (Lacy and Shackleton 2017; Palliwoda et al. 2017). The vegetation also serves as an integral component in soil and atmospheric systems (Liu et al. 2020; Piao et al. 2015; Tian et al. 2021).

Several studies about vegetation diversity have been carried out by researchers on several different topics such as plant diversity and the relationship between plant communities and environmental (Senbeta et al. 2014), diversity of tree vegetation in the forest (Alhani et al. 2015), plant diversity in traditional fruit gardens (Matius et al. 2018), diversity in Celetuh Geopark (Wulandari et al. 2018), vegetation analysis of karst (2020), diversity of urban parks (Sidik et al. 2021), diversity of wild edible plants to sustainable food security (Hassen 2021), diversity of medicinal plants in home gardens (Ramli et al. 2021), and maintaining tree biodiversity on the university (Susilowati et al. 2021).

The knowledge of the composition, structure, and diversity of vegetation species are some parameters that must be considered in managing campus vegetation and
GOS. Knowledge about vegetation based on the growth level is very significant in vegetation management so that the existence of vegetation is guaranteed in an area so that it will have a sustainable effect. Therefore, it is necessary to know the condition of the composition, structure, and diversity of vegetation species based on the growth level at Bina Widya Campus UNRI, so that vegetation management and GOS can be sustainable and function as they should. This study aims to identify the composition, structure, and diversity of vegetation species based on growth levels at Bina Widya Campus UNRI, Pekanbaru.

\section{MATERIALS AND METHODS}

\section{Study area}

This study was conducted at Bina Widya Campus University of Riau (UNRI), Pekanbaru, Indonesia (Figure 1). The selection of location was determined by using a purposive random sampling technique based on certain scientific considerations by looking at the condition of the existing vegetation, such as the density of plants, and the number of plants.

There were 11 locations where vegetation samples were documented (Figure 1). The location I: the front entrance to Subrantas street, II: the science park, III: next to the Faculty of Social and Political Sciences, IV: in front of the Mapala secretariat, Faculty of Economics, V: behind the wall climbing venue, VI: in front of the Chemistry building, Faculty of Mathematics and Natural Sciences, VII: in front of the canteen of the Faculty of Engineering, VIII: behind the Student Executive Board of the Faculty of Fisheries and Marine Sciences, IX: in front of the Dean of the Faculty of Fisheries and Marine Sciences, X: Arboretum, and XI: the back entrance lane SM Amin street.

\section{Data collection}

The selected procedure considered the conditions of the study area such as the distribution, amount and type of vegetation. Vegetation analysis was carried out using two procedures, i.e., belt transect and line transect. Belt transects are used in the green campus area, i.e., locations II, III, IV, V, VI, VII, VIII, IX, and X. At each location three plots were made, each plot measuring $20 \mathrm{~m} \times 20 \mathrm{~m}$ for tree level, $10 \mathrm{~m} \times 10 \mathrm{~m}$ for pole level, $5 \mathrm{mx} 5 \mathrm{~m}$ for sapling level, and $2 \mathrm{mx} 2 \mathrm{~m}$ for seedling level with nested pattern. While line transects are used in the longitudinal line area, i.e., locations I and XI. At each location, five plots were made, each measuring $4 \mathrm{~m} \times 100 \mathrm{~m}$. The plot is made from the guard post at the gate of UNRI to the inside of the campus. The samples measured were all levels of vegetation growth, such as seedlings, saplings, poles, and trees and recorded the names and number of individuals present in each plot. Species names were identified using references (Thomas 2011; Karyati and Adhi 2018), and verified with an online world database manufacturer (Plants of the World Online 2021). 

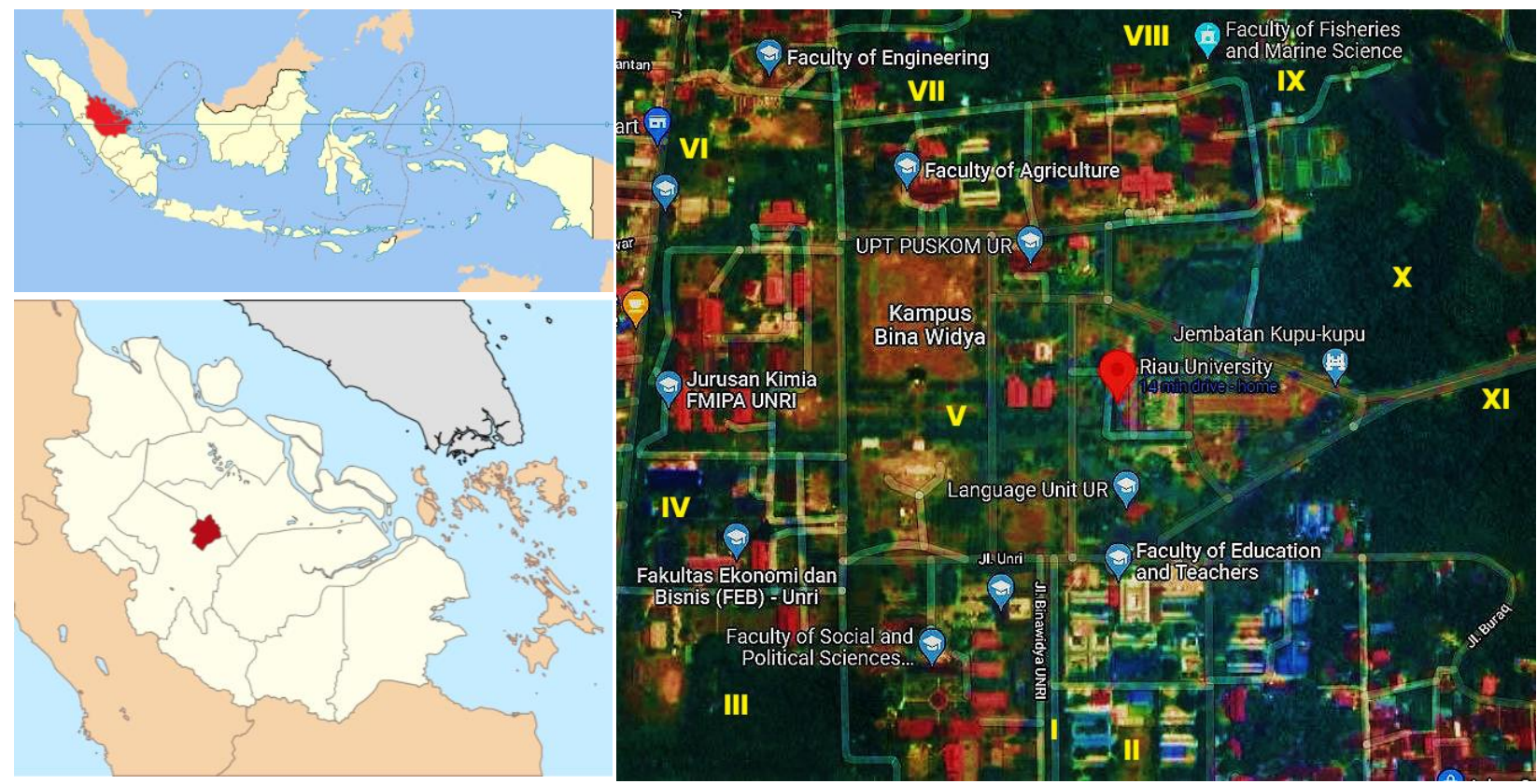

Figure 1. Study area at Bina Widya Campus of University of Riau, Pekanbaru, Indonesia with eleven study sites

\section{Data analysis}

The vegetation analysis was conducted to obtain quantitative information about the structure and composition of vegetation towards relative density (Whittaker 1975), relative frequency (Whittaker 1975), relative dominance which was calculated by using Simpson's formula (Odum 1993). The measurement of the important value index for each plant species was sum of relative density, relative frequency, and relative dominance (Mueller-Dombois 1984). The species diversity index was calculated using the Shannon-Wiener formula (Agrawal and Gopal 2013; Iskandar and Iskandar 2016; Shannon and Weavar 1949). An illustration of the distribution of individuals in a particular species of vegetation can be seen in the frequency value. The density of a species shows the number of individuals with a certain unit area. The species diversity index is an index that expresses community structure and ecosystem stability.

$$
\begin{aligned}
& \text { Relative density }(R D)=\frac{\text { Total number of individuals of species }}{\text { Total number of individuals of all species }} \times 100 \% \\
& \text { Relative frequency }(R F)=\frac{\text { Total frequency of species occur in all plots }}{\text { Total frequency of all species occur in all plots }} \times 100 \% \\
& \text { Relative dominance }(R D o)=\frac{\text { Total basal area of species }}{\text { Total basal area all species }} \times 100 \% \\
& \text { Important Value Index }(\mathrm{IVI})=\mathrm{RD}+\mathrm{RF}+\mathrm{RDo}
\end{aligned}
$$

Important Value Index (IVI) is to show the value of the ecological importance of a plant species in a particular ecosystem. The index is used for determining the rank of species based on their ecology importance. This indicator is used for determining dominant species in each level of growth around certain communities (Susilowati et al.
2020). The species diversity index used the following formula:

$$
\mathrm{H}^{\circ}=-\sum \text { piln pi }
$$

Where :

$\mathrm{Pi}=$ species composition

$\mathrm{ni}=$ significance value of species

$\mathrm{N}=$ significance of all species

The criteria for the species diversity index are if $H^{\prime}<1$ : low level of species diversity, $1<\mathrm{H}^{\prime}<3$ : medium level of species diversity, $\mathrm{H}^{\prime}>3$ : high level of species diversity. Wiener is a suitable index to calculate the level of species diversity (Suratissa and Rathnayake 2016).

\section{RESULTS AND DISCUSSION}

\section{The species composition}

The results showed that at the Bina Widya Campus UNRI, there were 33 species of trees, 29 species of poles, 16 species of saplings, and 8 species of seedlings from 44 species belonging to 22 families. The most common species was Swietenia macrophylla King with 289 individuals, the plant was found in the locations of I, V, VI, VII, X, and XI, in the growth levels of seedling, sapling, poles and trees and followed by Eucalyptus grandis W. Hill ex Maiden with 115 individuals, the plant was found in the locations of III and VII at the growth levels of poles and trees (Table 1).

Swietenia macrophylla is a plant that is suitable for pedestrians, especially in the entrance, because the leaves are dense, and has strong roots and branches so that the plant is not easily broken. The plant species is a large tree 
with a height of $35-40 \mathrm{~m}$ and diameter of $125 \mathrm{~cm}$, can reduce air pollution by around $47 \%-69 \%$, so it is called a protective tree as well as an air filter and water catchment area. The tree is able to survive in arid soil. Its leaves function to absorb the surrounding pollutants, dense foliage allows the removal of air pollutants, and provides shade (Ferrini et al. 2020). The leaves also release oxygen, which makes the surrounding environment become fresh. The soil and roots of Swietenia macrophylla King can bind the falling water, so that it becomes a water reserve (Syam 2020). The trees in urban areas must be resistant to high temperature pollutants, has limited root space, and be able to adapt to less water availability in compacted soils. The tree is currently listed as a "vulnerable" tree in the records of The International Union for Conservation of Nature (World Conservation Monitoring Centre 1998). The campus of GOS can also function as a savior for other endangered plants and as a place for ex-situ cultivation. There were 20 species of plants found in the location X Arboretum, such as Alstonia scholaris (L) R.Br, Annona muricata L, Archidendron pauciflorum (Bent.) I.C Nielsen, Averrhoa bilimbi L, Callerya atropurpurea (Wall) Schot, Calophyllum macrocarpum Hook.f, Endospermum diadenum (Miq), Ficus benjamina L, Hevea brasiliensis (Willd. Ex A.Juss.) Mull.Arg, Palaquium burchii H.J.L, Pentaspadon motley Hook.f, Porterandia anisophylla (Jack ex Roxb.) Ridl, S. macrophylla, Samanea saman (Jacq.) Merr, Scorodocarpus bornestratum (Baill.) Becc, Shorea leprosula Miq, Syzygium antisepticum (Blume) Merr. \& L.M.Perry, Terminalia catappa L, Acacia mangium Willd, Vitex pinnata L. Meanwhile, the location with the fewest species was found in location I, with 3 species, i.e. S. macrophylla, Pterocarpus indicus Willd and Adenanthera pavonina L. The composition and structure of the vegetation community are influenced by phenology, dispersal, and natality (Kimmins 1987). Its success as a new individual is influenced by the different fertility and fecundity in each species.

The number of individuals was 874, it consisted of 534 tree individuals, 207 pole individuals, 87 sapling individuals, and 46 seedling individuals (Figure 3). The predominant growth level was the tree, followed by pole, sapling, and seedling. The highest number of individuals at the tree level was found at the location I (109 individuals), and location XI (117 individuals). The plants planted at the entrance of Bina Widya Campus was still dominated by road shading plants, such as S. macrophylla. This plant has a function as a shade, air pollution reduction, and air filter so that it makes the air around the campus become fresh (Chen et al. 2017; Tiwary and Kumar 2014). This plant has strong roots to avoid vehicle vibrations, is easy to grow in hot areas, and is resistant to wind, making it suitable for use as a shade plant. In addition, the sides plants can absorb pollution elements from motor vehicle fumes, especially lead $(\mathrm{Pb})$, because the campus entrance is not only always passed by the academic community on foot but also by riding the motorbikes and cars.

Plants that are cultivated should have the ability to absorb pollutants, which will help in the improvement of environmental conditions (Gratani et al. 2016; Ives et al. 2016).

\section{The vegetation structure}

Table 2 showed that the highest relative density of trees was A. scholaris (100\%), found at location IX followed by S. macrophylla $(99.15 \%)$ at location XI, and E. grandis (97.65\%) at location III. The lowest density was $A$. scholaris $(23.29 \%)$ at location $\mathrm{X}$. The relative density value is an illustration of the number of species in each location. The highest relative frequency value was $A$. scholaris (100\%) at location IX, followed by S. macropylla $(90.91 \%)$ at location XI. The lowest relative frequency was $A$. scholaris $(13.89 \%)$ at location $\mathrm{X}$. The success of each species of vegetation to survive in a certain area is influenced by all physical environmental factors (temperature, light, soil structure, humidity), biotic factors (interaction among species, competition, parasitism), and chemical factors including water availability, oxygen, $\mathrm{pH}$, interacting nutrients in the soil (Krebs 1994). The relative dominance value of each vegetation species is influenced by the density of species, and the average diameter (at breast height) of mainly tree vegetation. The highest relative dominance species was A. scholaris (100\%) at location IX, and the lowest was Rhodamnia cinerea Jack $(18.48 \%)$ at location VIII. The relative domination indicates the land surface area that has been covered by a plant species (Odum 1993).

Table 1. The growth levels of vegetation composition at Bina Widya Campus, University of Riau, Pekanbaru, Indonesia

\begin{tabular}{|c|c|c|c|c|c|c|c|c|}
\hline Family & Spesies name & Local name & $\begin{array}{c}\text { Location found } \\
\text { (see Figure 1) }\end{array}$ & $\mathbf{T}$ & $\mathbf{P}$ & $\mathbf{S a}$ & $\mathbf{S}$ & Total \\
\hline Anacardiaceae & Pentaspadon motley Hook.f & Pelajau & $\mathrm{X}$ & - & 2 & - & - & 2 \\
\hline Annonaceae & Annona muricata $\mathrm{L}$ & Sirsak & $1 \mathrm{X}$ & - & - & 1 & - & 1 \\
\hline \multirow[t]{5}{*}{ Apocynaceae } & Alstonia scholaris (L) R.Br & Pulai & II & - & - & 1 & - & 1 \\
\hline & & & III & 2 & 2 & - & - & 4 \\
\hline & & & VI & 38 & 4 & - & - & 42 \\
\hline & & & IX & 7 & - & - & - & 7 \\
\hline & & & $\mathrm{X}$ & 17 & 5 & & & 22 \\
\hline \multirow[t]{4}{*}{ Arecaceae } & Arenga pinnata (Wurmb) Merr & Aren & VI & 1 & - & - & - & 1 \\
\hline & Cocos nucifera $\mathrm{L}$ & Kelapa & V & 1 & - & - & - & 1 \\
\hline & Elaeis guineensis Jacq & Sawit & VII & 24 & - & - & - & 24 \\
\hline & Roystonea regia (Kunth) O.F.Cook & Palem Raja & $\mathrm{V}$ & 1 & 2 & - & - & 3 \\
\hline
\end{tabular}




\begin{tabular}{|c|c|c|c|c|c|c|c|}
\hline \multirow[t]{3}{*}{ Clusiaceae } & Calophyllum macrocarpum Hook.f & Bintangor & $\mathrm{X}$ & 2 & - & - & 2 \\
\hline & Garcinia mangostana $\mathrm{L}$ & Manggis & VI & - & 2 & - & 2 \\
\hline & & & IX & - & - & - & 1 \\
\hline \multirow[t]{4}{*}{ Combretaceae } & Terminalia catappa $\mathrm{L}$ & Ketapang & II & 1 & - & - & 1 \\
\hline & & & III & - & 1 & - & 1 \\
\hline & & & VI & 2 & 2 & - & 4 \\
\hline & & & $\mathrm{X}$ & - & - & 1 & 1 \\
\hline Dipterocarpaceae & Shorea leprosula Miq & Meranti Bunga & $X$ & 5 & 3 & 2 & -10 \\
\hline \multirow[t]{5}{*}{ Euphorbiaceae } & Endospermum diadenum (Miq.) Airy Shaw & Sendok-sendok & VIII & 1 & - & - & 1 \\
\hline & & & $\mathrm{X}$ & - & 1 & - & 1 \\
\hline & Hevea brasiliensis (Willd. Ex A.Juss.) Mull.Arg & Karet & II & 8 & 5 & - & 13 \\
\hline & & & $\mathrm{X}$ & 13 & 11 & 2 & 30 \\
\hline & Hura crepitans L & Kalpataru & $\mathrm{V}$ & 2 & - & - & 2 \\
\hline \multirow[t]{17}{*}{ Fabaceae } & Acacia mangium Willd & Akasia & IV & - & 2 & - & 3 \\
\hline & & & VII & - & - & 1 & 2 \\
\hline & & & $X$ & - & - & 15 & 24 \\
\hline & & & XI & - & - & - & 6 \\
\hline & Adenanthera pavonina $\mathrm{L}$ & Saga & I & 4 & - & - & 4 \\
\hline & & & IV & 4 & - & - & 4 \\
\hline & & & $\mathrm{V}$ & 4 & 2 & - & 6 \\
\hline & & & VI & 2 & - & - & 2 \\
\hline & & & VII & - & - & 3 & 4 \\
\hline & Archidendron pauciflorum (Bent.) I.C Nielsen & Jengkol & IV & 1 & - & - & 1 \\
\hline & & & VII & 2 & - & - & 2 \\
\hline & & & $\mathrm{X}$ & 1 & & & 1 \\
\hline & Callerya atropurpurea (Wall.) Schot & Merimbungan & $\mathrm{X}$ & 5 & 4 & 1 & 10 \\
\hline & Cynometra ramiflora $\mathrm{L}$ & Kepel & XI & - & 1 & - & 1 \\
\hline & Erythrina crista-galli $\mathrm{L}$ & Dadap Merah & $\mathrm{V}$ & 1 & - & - & 1 \\
\hline & Pterocarpus indicus Willd & Angsana & I & 46 & 13 & 9 & 68 \\
\hline & Samanea saman (Jacq.) Merr & Trembesi & $\mathrm{X}$ & - & 4 & - & 4 \\
\hline \multirow[t]{5}{*}{ Lamiaceae } & Trema micrantha (L.) Blume & Mengkirai & II & - & 1 & - & 1 \\
\hline & Vitex pinnata $\mathrm{L}$ & Laban & II & 1 & - & 1 & 2 \\
\hline & & & IV & 3 & 15 & 11 & 32 \\
\hline & & & VIII & 4 & 4 & 1 & 9 \\
\hline & & & $X$ & 8 & 14 & 6 & 37 \\
\hline \multirow[t]{2}{*}{ Malvaceae } & Durio zibethinus Moon & Durian & VI & 1 & - & - & 1 \\
\hline & Hibiscus tiliaceus $\mathrm{L}$ & Waru & VII & - & 1 & 2 & 4 \\
\hline \multirow[t]{6}{*}{ Meliaceae } & Swietenia macrophylla King & Mahoni & I & 59 & 25 & 1 & 90 \\
\hline & & & V & 3 & - & - & 3 \\
\hline & & & VI & 2 & 1 & - & 3 \\
\hline & & & VII & 1 & - & 10 & 11 \\
\hline & & & $X$ & 8 & 6 & 1 & -15 \\
\hline & & & XI & 116 & 39 & 8 & $4 \quad 167$ \\
\hline \multirow{4}{*}{ Moracaceae } & Artocarpus heterophyllus Lam & Nangka & $\mathrm{V}$ & 1 & - & - & 1 \\
\hline & & & XI & 1 & - & - & 1 \\
\hline & Artocarpus integer (Thunb.) Merr & Cempedak & IX & - & 1 & - & 1 \\
\hline & Ficus benjamina $\mathrm{L}$ & Beringin & $\mathrm{X}$ & 1 & - & - & 1 \\
\hline \multirow[t]{6}{*}{ Myrtaceae } & Eucalyptus grandis W.Hill ex Maiden & Eukaliptus & III & 83 & 13 & - & -96 \\
\hline & & & VII & 19 & - & - & $-\quad 19$ \\
\hline & Rhodamnia cinerea Jack & Marpoyan & VIII & 6 & 5 & 4 & 15 \\
\hline & & & $\mathrm{X}$ & - & 2 & 2 & 4 \\
\hline & Syzygium antisepticum (Blume) Merr. \& L.M.Perry & Kelat & $\mathrm{X}$ & 4 & 2 & 1 & 7 \\
\hline & Syzygium polycephalum (Miq.) Merr. \& .M.Perry & Gowok & VIII & - & 2 & - & 2 \\
\hline Olacaceae & Scorodocarpus borneensis (Baill.) Becc & Kulim & $\mathrm{X}$ & 1 & - & - & - \\
\hline Oxalidaceae & Averrhoa bilimbi $\mathrm{L}$ & Belimbing wuluh & $\mathrm{X}$ & 1 & - & - & 1 \\
\hline Phyllanthaceae & Baccaurea macrocarpa (Miq.) Mull.Arg & Tampui & IX & - & 1 & 1 & 2 \\
\hline Rubiaceae & Porterandia anisophylla (Jack ex Roxb.) Ridl & Kopi-kopi & $\mathrm{X}$ & 1 & - & - & 1 \\
\hline \multirow[t]{2}{*}{ Sapindaceae } & Nephelium mutabile Blume & Pulasan & $X$ & 1 & 1 & - & 2 \\
\hline & Pometia pinnata J.R.Forst. \& G.Forst & Matoa & V & 7 & - & - & 7 \\
\hline \multirow[t]{2}{*}{ Sapotaceae } & Palaquium rostratum (Miq.) Burck & Nagasari & VIII & 1 & - & - & 1 \\
\hline & Palaquium burchii H.J.L & Balam & $\mathrm{X}$ & 2 & - & - & 2 \\
\hline Theaceae & Eurya acuminata DC & Jenggitri & VIII & - & 2 & - & 2 \\
\hline \multirow[t]{2}{*}{ Thymelaceae } & Aquilaria malaccenis Lam & Gaharu & VIII & 1 & - & - & 1 \\
\hline & & & $X$ & 3 & 6 & 2 & 112 \\
\hline Total of ind. & 534 & 207 & 87 & 46 & 874 & & \\
\hline Total of species & 33 & 29 & 16 & 8 & & & \\
\hline
\end{tabular}

Notes: S: Seedling; Sa: Sapling; P: Poles; T: Trees; -: Absent 


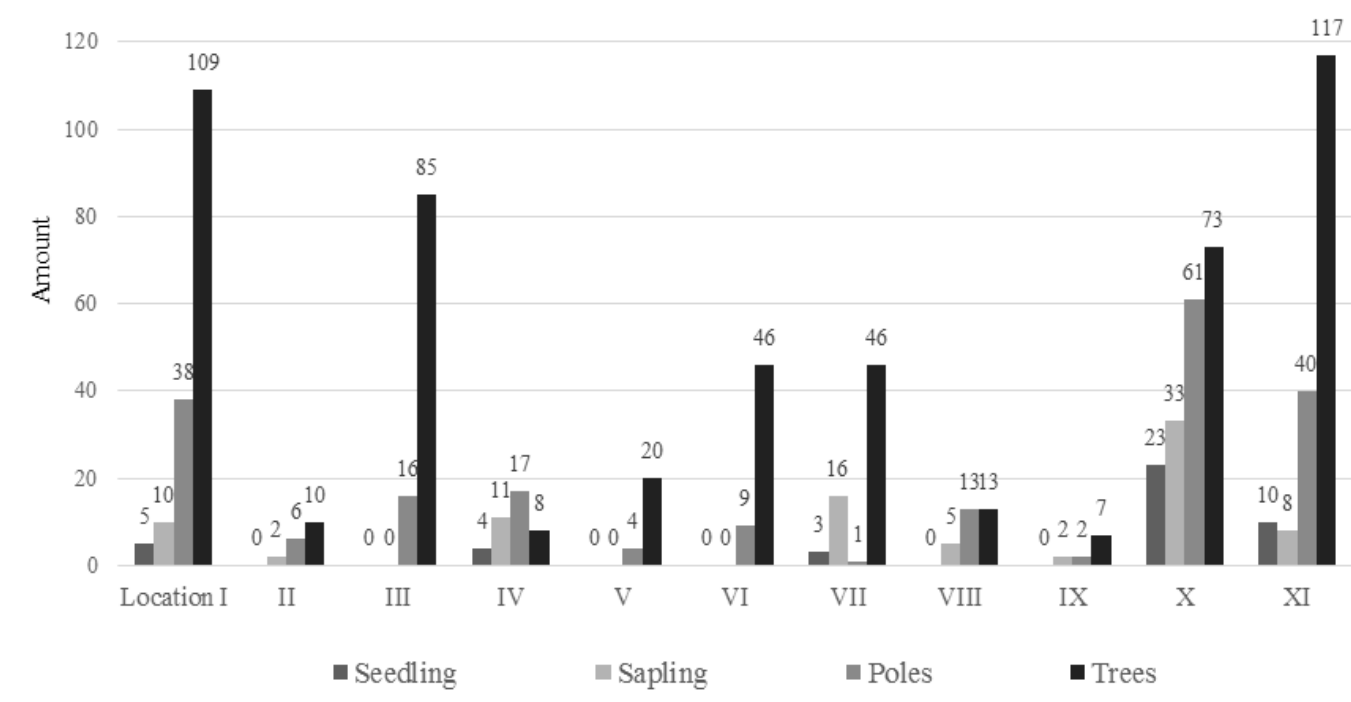

Figure 3. The number of individuals by growth level in each location at Bina Widya Campus, University of Riau, Pekanbaru, Indonesia

The highest IVI of trees at each location was different from one another. The highest IVI was A. scholaris (300\%) at location IX, followed by S. macrophylla (289.39\%) at location XI. The species with the highest IVI value are the dominant species and they have an important role and effect on the ecology compared to other species. Important Value Index is one of the parameters which can provide an overview of the role of the species that are concerned in the community (Sundarapandian and Swamy 2000).

Table 3 showed that $H$. tiliaceus at location VII had the highest relative density (100\%), relative frequency (100\%), and relative dominance (100), while $V$. pinnata at location $\mathrm{X}$ had the lowest relative density $(22.95 \%)$, relative frequency $(16 \%)$, and relative dominance $(20.07 \%)$. The highest IVI species was $H$. tiliaceus $(300 \%)$, found at location VII, while the lowest IVI species was $V$. pinnata $(59.02 \%)$ at location X. The dominance value was obtained from species density and stem diameter. The vegetation species that has a high density and a high level of dominance indicates a large average diameter and has many individuals. Swietenia macrophylla will sustain because of its high density and distribution, especially at pole level, while $H$. tiliaceus is the dominant species at pole level, with the largest number of individuals, and widely distributed so that the species has the potential to replace the dominance of $E$. guineensis at the tree level because $H$. tiliaceus has a good regeneration with a high IVI, The highest IVI species at the sapling level were $V$. pinnata (300\%, location IV), and S. macrophylla (300\%, location XI), followed by $P$. indicus $(246.16 \%$, location I) (Table 4). Meanwhile, in the locations of III, V, VI, no sapling vegetation was found. The vegetation at these locations were only trees and poles. Location III was dominated by $E$. grandis at tree and pole levels. Location V was dominated by $P$. pinnata at tree level, and A. pavonina at pole level. Location VI was dominated by, A. scholaris at tree and pole levels.

Table 5 showed that the highest IVI species were $S$. macrophylla $(300 \%)$ at location I, and G. mangostana $(300 \%)$ at location IX. This shows that the density of species distribution and the area occupied is high. Swietenia macrophylla at location I was not only found at the seedling level, but also found at the levels of tree and poles but not at the sapling level. The availability of $S$. macrophylla found at seedling, pole, and tree levels indicate that the species has high adaptability in the location. At locations of II, III, V, VI, and VIII, only vegetation at the levels of tree and pole were found, and no vegetation at the seedling level. Considering that mostly sapling and no seedling not found in locations of II, III, V, VI, and VIII, Bina Widya Campus needs to be reforested so that GOS remains sustainable.

\section{The species diversity}

The diversity of vegetation species from seedlings to trees ranged from 0-2.34 (low-medium). The species diversity indices of seedling, sapling, pole or tree found at locations of V, VI, VII, VIII, IX and X ranged from 1.042.34 (medium), while other locations of I, II, III, IV, and $\mathrm{XI}$ were at the range of $0.72-0.98$ (low). The overall species diversity index ranged from 0.72-7.57 (low-high). The average vegetation diversity index at Bina Widya Campus, UNRI was 2.44 (medium) (Table 6). This is due to the fact that the species diversity index is not spread evenly in each place, with high, medium, and low values. The lowest species diversity index was found at location III (0.72), while the highest was found at location X (7.57). This demonstrates that many types of plants are capable of adapting and winning the competition to reach the level of tree development. The high species diversity index at location $\mathrm{X}$ was due to the large number of plant species found, which were 190 individuals belonging to 20 species. The better the species diversity index means the more stable an ecosystem. If there are more species diversity at one location, the community will be more stable at that location. Ecosystem stability is characterized by species richness, species diversity, and even distribution of species. Ecosystem stability will provide benefits for the environment and humans (Suratissa and Rathnayake 2016). 
Table 2. The highest IVI of trees level vegetation at Bina Widya Campus, University of Riau, Pekanbaru, Indonesia

\begin{tabular}{llllll}
\hline Location & Species name & RD $(\%)$ & RF $(\%)$ & RDo $(\%)$ & IVI $(\%)$ \\
\hline I & Swietenia macrophylla King & 54.13 & 41.67 & 57.41 & 153.19 \\
II & Hevea brasiliensis (Willd. Ex A.Juss.) Mull.Arg & 88.89 & 75 & 90.41 & 254.30 \\
III & Eucalyptus grandis W.Hill ex Maiden & 97.65 & 75 & 93.95 & 266.59 \\
IV & Adenanthera pavonina L & 50 & 40 & 82.72 & 172.72 \\
V & Pometia pinnata (L) R.Br & 35 & 27.27 & 24.10 & 86.37 \\
VI & Alstonia scholaris L & 82.60 & 33.33 & 80.23 & 196.17 \\
VII & Elaeis guineensis Jacq. & 52.17 & 33.33 & 54.20 & 139.71 \\
VIII & Rhodamnia cinerea Jack & 46.15 & 14.28 & 18.48 & 78.92 \\
IX & Alstonia scholaris (L) R.Br & 100 & 100 & 100 & 300 \\
X & Alstonia scholaris (L) R.Br & 23.29 & 13.89 & 32.29 & 69.47 \\
XI & Swietenia macrophylla King & 99.15 & 90.91 & 99.34 & 289.39 \\
\hline
\end{tabular}

Notes: RD: Relative Density; RF: Relative Frequency; RDo: Relative Dominance; IVI: Important Value Index

Table 3. The highest IVI of poles level vegetation at Bina Widya Campus, University of Riau, Pekanbaru, Indonesia

\begin{tabular}{llllll}
\hline Location & Species name & RD $(\%)$ & RF $(\%)$ & RDo $(\%)$ & IVI $(\%)$ \\
\hline I & Swietenia macrophylla King & 65.79 & 50 & 69.53 & 185.32 \\
II & Hevea brasiliensis (Willd. Ex A.Juss.) Mull.Arg & 83.33 & 66.67 & 93.31 & 243.31 \\
III & Eucalyptus grandis W.Hill ex Maiden & 81.25 & 60 & 86.87 & 228.12 \\
IV & Vitex pinnata L & 83.33 & 60 & 86.42 & 229.75 \\
V & Adenanthera pavonina L & 50 & 50 & 52 & 152 \\
VI & Alstonia scholaris (L) R.Br & 44.44 & 33.33 & 58.37 & 136.14 \\
VII & Hibiscus tiliaceus L & 100 & 100 & 100 & 300 \\
VIII & Rhodamnia cinerea Jack & 38.46 & 20 & 38.16 & 96.62 \\
IX & Baccaurea macrocarpa (Miq.) Mull.Arg & 50 & 50 & 54.58 & 154.58 \\
X & Vitex pinnata L & 22.95 & 16 & 20.07 & 59.02 \\
XI & Swietenia macrophylla King & 97.5 & 90 & 98.60 & 286.10 \\
\hline
\end{tabular}

Table 4. The highest IVI of saplings level vegetation at Bina Widya Campus, University of Riau, Pekanbaru, Indonesia

\begin{tabular}{llllll}
\hline Location & Species name & RD $(\%)$ & RF $(\%)$ & RDo $(\%)$ & IVI $(\%)$ \\
\hline I & Pterocarpus indicus & 90 & 83.33 & 72.83 & 246.16 \\
II & Alstonia scholaris (L) R.Br & 50 & 50 & 64.48 & 164.48 \\
III & - & - & - & - & - \\
IV & Vitex pinnata L & 100 & 100 & 100 & 300 \\
V & - & - & - & - & - \\
VI & - & - & - & - & - \\
VII & Swietenia macrophylla King & 62.5 & 42.86 & 62.27 & 167.63 \\
VIII & Rhodamnia cinerea Jack & 80 & 50 & 95.15 & 225.15 \\
IX & Baccaurea macrocarpa & 50 & 50 & 76.53 & 176.53 \\
X & Acacia mangium Willd & 45.46 & 14.29 & 14.44 & 74.18 \\
XI & Swietenia macrophylla King & 100 & 100 & 100 & 300 \\
\hline
\end{tabular}

Table 6. The number of species and index of species diversity at Bina Widya Campus, University of Riau, Pekanbaru, Indonesia

\begin{tabular}{|c|c|c|c|c|c|c|c|c|c|}
\hline \multirow[t]{3}{*}{ Location } & \multicolumn{8}{|c|}{ Growth level } & \multirow{3}{*}{ H' (Level) } \\
\hline & \multicolumn{2}{|c|}{ Seedling } & \multicolumn{2}{|c|}{ Sapling } & \multicolumn{2}{|c|}{ Poles } & \multicolumn{2}{|c|}{ Trees } & \\
\hline & $\Sigma$ sp & H' & $\Sigma$ sp & H' & $\Sigma$ sp & H' & $\Sigma \mathrm{sp}$ & H' & \\
\hline I & 1 & 0 & 2 & 0.33 & 2 & 0.64 & 3 & 0.82 & 1.79 (Medium) \\
\hline II & 0 & 0 & 2 & 0.69 & 2 & 0.15 & 2 & 0.35 & 1.19 (Medium) \\
\hline III & 0 & 0 & 0 & 0 & 3 & 0.60 & 2 & 0.12 & 0.72 (Low) \\
\hline IV & 3 & 0.96 & 1 & 0 & 3 & 0.56 & 3 & 0.98 & 2.50 (Medium) \\
\hline $\mathrm{V}$ & 0 & 0 & 0 & 0 & 2 & 0.69 & 8 & 1.81 & 2.50 (Medium) \\
\hline VI & 0 & 0 & 0 & 0 & 4 & 1.27 & 6 & 0.74 & 2.01 (Medium) \\
\hline VII & 3 & 1.10 & 4 & 1.04 & 1 & 0 & 4 & 0.93 & 3.07 (High) \\
\hline VIII & 0 & 0 & 2 & 0.50 & 4 & 1.31 & 5 & 1.32 & 3.13 (High) \\
\hline IX & 1 & 0 & 2 & 0.69 & 2 & 0.69 & 1 & 0 & 1.38 (Medium) \\
\hline $\mathrm{X}$ & 4 & 1.17 & 11 & 1.77 & 13 & 2.28 & 16 & 2.34 & 7.56 (High) \\
\hline XI & 2 & 0.67 & 1 & 0 & 2 & 0.12 & 2 & 0.05 & 0.84 (Low) \\
\hline Average & & & & & & & & & 2.44 (Medium) \\
\hline
\end{tabular}


Table 5. The highest IVI of seedlings level vegetation at Bina Widya Campus, University of Riau, Pekanbaru, Indonesia

\begin{tabular}{llllll}
\hline Location & Species name & RD $(\%)$ & RF $(\%)$ & RDo $(\%)$ & IVI $(\%)$ \\
\hline I & Swietenia macrophylla King & 100 & 100 & 100 & 300 \\
II & - & - & - & - & - \\
III & - & - & - & - & - \\
IV & Vitex pinnata L & - & 60 & 59.44 & 179.44 \\
V & - & - & - & - & - \\
VI & - & 33.33 & 33.33 & - & - \\
VII & Hibiscus tiliaceus L & - & - & - & - \\
VIII & - & 100 & 100 & 100 & 300 \\
IX & Garcinia mangostana L & 39.13 & 37.5 & 33.82 & 110.45 \\
X & Vitex pinnata L & 60 & 25 & 66.99 & 151.99 \\
XI & Acacia mangium Willd & & & & \\
\hline
\end{tabular}
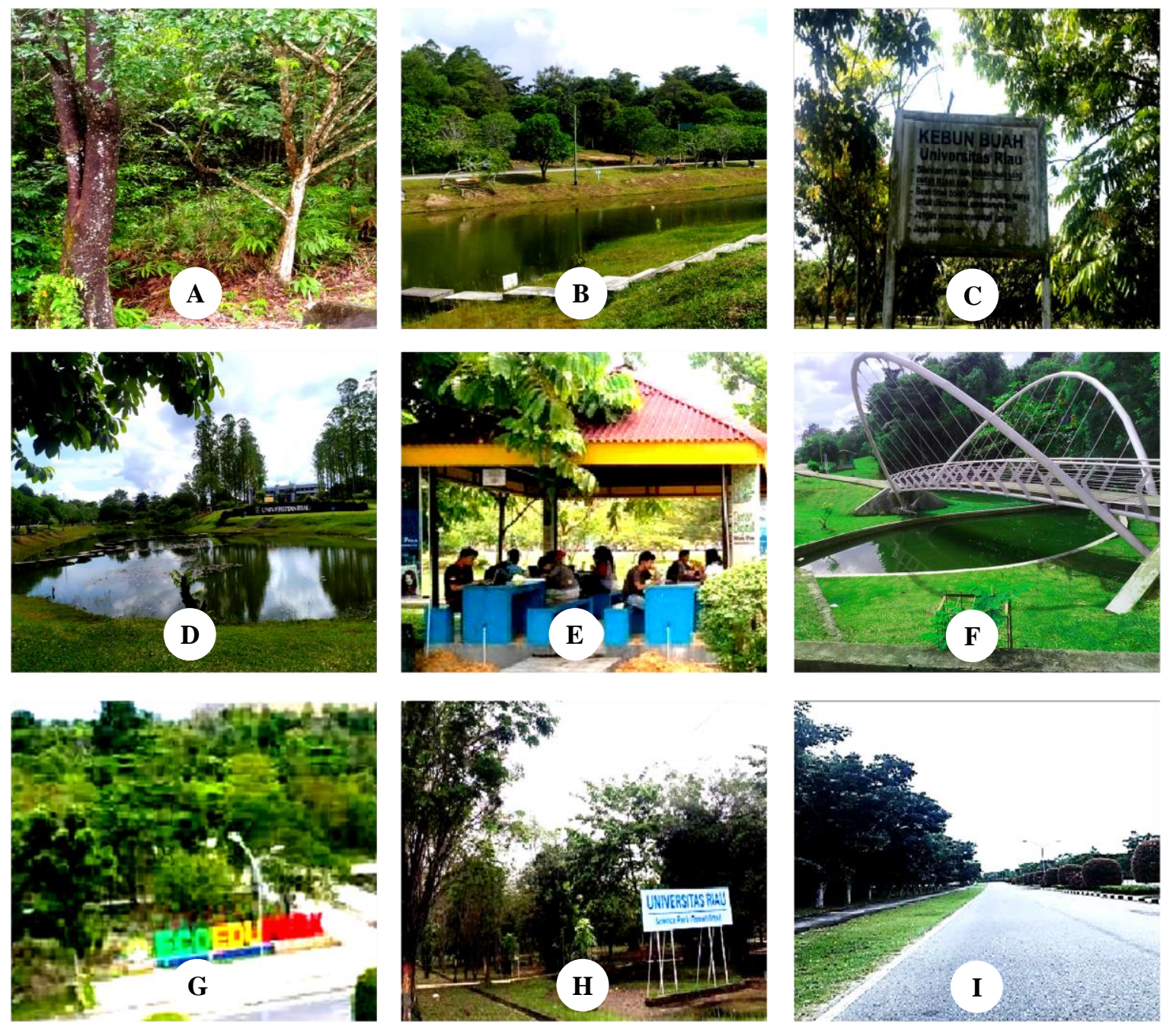

Figure 4. Some areas of vegetation: A. Urban forest /Arboretum; B. Tree vegetation; C. Fruit garden; D. Rectorate park; E. Educational garden; F. Butterfly park; G. Ecoedupark; H. Science park; I. Greenline

Location $\mathrm{X}$ is an urban forest where the vegetation is more natural than others so that the vegetation species are more diverse. The Bina Widya Campus is also part of the GOS of the City of Pekanbaru. Riau University was appointed as an urban forest based on the collaboration between the university and the Municipality Government of Pekanbaru, reinforced by the Decree of the Mayor of Pekanbaru No. 94 of 2007 concerning the designation of the location of urban forests at Bina Widya Campus area (Pusat Studi Lingkungan Hidup 2019). The species of the urban forest at Bina Widya Campus are the species of protection and the type of germplasm conservation. 
Scorodocarpus borneensis and S. leprosula are rare and local superior species because their woods are used to build a boat at the 'Pacu Jalur' festival. The festival is one of the traditions or local wisdom of the people of Kuantan Singingi Regency in particular, and the people of Riau Province in general, and held once a year. Vegetation species have different roles (Ferrini et al. 2020) such as medicine, food, clothing, boards, traditional and religious ceremonies. The vegetation of the Bina Widya Campus can be grouped into urban forest, tree lots, parks, and gardens (Figure 4).

\section{ACKNOWLEDGEMENTS}

We convey our high appreciation and gratitude to Riau University, Indonesia which has provided facilities and financial assistance so that this study can be carried out which is part of the dissertation for the first author. Thanks are also conveyed to Aden Iskandar, Syafaat, Ikhbal, Kea, and Balqis who have contributed a lot in the correction and translation to English, photo editing, and location maps.

\section{REFERENCES}

Agrawal A, Gopal K. 2013. Application of diversity index in measurement of species diversity. Biomonitoring of water and waste water. Springer, India. DOI: 10.1007/978-81-322-0864-8.

Alhani F, Manurung TF, Darwati H. 2015. Diversity of tree vegetation in the forest with special purpose area (KHDTK) Samboja Kutai Kartanegera Regency East Kalimantan. Jurnal Hutan Lestari 3 (4): 590-598. [Indonesian]

Alshuwaikhat, Habib M, Ismaila A. 2008. An integrated approach to achieving campus sustainability: Assessment of the current campus environmental management practices. J Cleaner Prod 16 (16): 1777 1785. DOI: $10.1016 /$ j.jclepro.2007.12.002.

Bagheri Z, Nadoushan MA, Abari MF. 2017. Evaluation of the effect of green space on air pollution dispersion using satellite images and landscape metric: A case study of Isfahan City. Fresenius Environ Bull 26 (12A): 8135-8145.

Basrowi M, Hendra M, Hariani N. 2018. Komposisi dan struktur pohon ripa rian di Sungai Kahala Kabupaten Kutai Kartanegara. Jurnal Pro Life 5 (3): 637-649. [Indonesian]

Chen L, Liu C, Zhang L, Zou R, Zhang Z. 2017. Variation in tree species ability to capture and retain airbome fine particulate matter (PM2.5) Sci Rep 7 (1): 1-11. DOI: 10.1038/s41598-017-03360-1.

Ferrini F, Fini A, Mori J, Gori A. 2020. Role of vegetation as a mitigating factor in the urban context. Sustainability 12 (10): 4247. DOI: $10.3390 / \mathrm{su} 12104247$.

Gratani L, Laura V, Andrea B. 2016. Carbon sequestration of four urban parks in Rome. Urban For Urban Greening 19: 184-193. DOI 10.1016/ j.ufug.2016.07.007.

Gulwadi GB, Mishchenko ED, Hallowell G, Alves S, Kennedy M. 2019. The restorative potential of a university campus: Objective greenness and student perceptions in Turkey and the United States. Landsch Urban Plan 187: 36-46. DOI: 10.1016/j.landurbplan 2019.03.003.

Hanan H. 2013. Open space as meaningful place for students in ITB campus. Proc Soc Behav Sci 85: 308-317. DOI: 10.1016/j.sbspro.2013.08.361.

Hassen A. 2021. Diversity and potential contribution of wild edible plants to sustainable food security in North Wollo, Ethiopia. Biodiversitas 22 (6): 2501-2510. DOI: 10.13057/biodiv/d220660.

Herdiansyah H, Negoro HA, Rusdayanti N, Shara S. 2020. Palm oil plantation and cultivation: Prosperity and productivity of smallholders. Open Agric 5 (1): 617-630. DOI: 10.1515/opag20200063.
Iskandar J, Iskandar B. 2016. Plant architecture: Structure of village homegarden and urban green space. Teknosain, Yogyakarta, Indonesia. [Indonesian]

Ives CD, Lentini PE, Threlfall CG, Ikin K, Shanahan DF, Garrard GE Bekessy SA, Fuller RA, Mumaw L, Rayner L. 2016. Cities are hotspots for threatened species. Glob Ecol Biogeogr 25 (1): 117-126 DOI: $10.1111 /$ geb.12404.

Jones KR. 2018. 'The lungs of the city': Greenspace, public health and bodily metaphor in the landscape of urban park history. Environ Hist Camb 24 (1): 39-58. DOI: 10.3197/096734018X15137949591837.

Karyati, Adhi MA. 2018. Types of Understorey in The Educational Forest of the Faculty of Forestry, Mulawarman University. Mulawarman University Press, Samarinda, Indonesia. [Indonesian]

Kimmins JP. 1987. Forest ecology. Macmillan Publishing Co, New York.

Krebs CJ. 1994. Ecology, The Experimental Analysis of Distribution and Abundance. Addison-Wesley Educational Publishers, New York.

Lacy P De, Shackleton C. 2017. Aesthetic and spiritual ecosystem services provided by urban sacred sites. Sustainability 9 (9): 1628 . DOI: $10.3390 / \mathrm{su} 9091628$.

Liu L, Gudmundsson L, Hauser M, Qin D, Li S, Seneviratne SI. 2020. Soil moisture dominates dryness stress on ecosystem production globally. Nature 11 (1): 1-9. DOI: 10.1038/s41467-020-18631-1.

Matius P, Tjwa SJM, Raharja M, Sapruddin, Noor S, Ruslim Y. 2021. Plant diversity in traditional fruit gardens (munaans) of Benuaq and Tunjung Dayaks tribes of West Kutai, East Kalimantan, Indonesia. Biodiversitas 19 (4): 1280-1288. DOI: 10.13057/biodiv/d190414.

Mueller-Dombois D, Heinz Ellenberg H. 1984. Aims and Methods of Vegetation Ecology. John Wiley and Sons, New York.

Odum EP. 1993. Fundamentals of Ecology, 4th ed. WB Sunder's Co, New York.

Palliwoda J, Kowarik I, von der Lippe M. 2017. Human-biodiversity interactions in urban parks: The species level matters. Landsch Urban Plan 157: 394-406. DOI: 10.1016/j.landurbplan.2016.09.003.

Piao S, Yin G, Tan J, Cheng L, Huang M, Li Y, Liu R, Mao J, Myneni RB, Peng S, Poulter B, Shi X, Xiao Z, Zeng N, Wang Y. 2015. Detection and attribution of vegetation greening trend in China over the last 30 years. Glob Change Biol 21 (4): 1601-1609. DOI: $10.1111 / \mathrm{gcb} .12795$.

Podhrazka J, Kucera J, Doubrova D, Dolezal P. 2021. Functions of windbreaks in the landscape ecological network and methods of their evaluation. Forests 12 (1): 67. DOI: 10.3390/f12010067.

Plants of the World Online (POWO). 2021. Swietenia macrophylla King. http://www.plantsoftheworldonline.org/results?q=Swietenia\%20macr ophylla. [22-10-2021]

Purnomohadi N. 2006. Ruang terbuka hijau sebagai unsur utama tata ruang kota, Dirjen Penataan Ruang Kementerian Pekerjaan Umum, Jakarta, Indonesia. [Indonesian]

Pusat Studi Lingkungan Hidup (PSLH). 2019. Dokumen Addendum Andal RKL-RPL Kampus Bina Widya Universitas Riau Pekanbaru. UNRI Press, Pekanbaru. [Indonesian]

Ramli MR, Milow P, Malek S. 2021. Diversity and traditional knowledge of medicinal plants in home gardens of Kampung Masjid Ijok, Perak, Malaysia. Biodiversitas 22(5): 2458-2465. DOI: 10.13057/biodiv/d220502.

Rózová Z, Supuka J, Klein J, Jasenka M, Tóth A, Štefl L. 2020. Effect of vegetation structure on urban climate mitigation. Acta Hortic Regiotect 23 (2): 60-65. DOI: 10.2478/ahr-2020-0013.

Scholl K, Gulwadi G, Betrabet G. 2015. Recognizing campus landscapes as learning spaces. J Learn Spaces 4 (1): 16-24.

Senbeta F, Schmit C, Woldemariam T, Boehmer HJ, Denich M. 2014. Plant diversity, vegetation structure and relationship between plant communities and environmental variables in the afromontane forests of Ethiopia. SINET Ethiopian J Sci 37 (2): 113-130.

Shan X. 2014. Socio-demographic variation in motives for visiting urban green spaces in a large Chinese city. Habitat Intl 41: 114-120. DOI: 10.1016/j.habitatint.2013.07.012.

Shannon C E, Weaver, W. 1949. The mathematical theory of communication. The University of Illinois Press, Urbana, IL, USA.

Muhlisin, Iskandar J, Gunawan B, Cahyandito MF. 2021. Vegetation diversity and structure of urban parks in Cilegon City,Indonesia, and local residents' perception of its function. Biodiversitas 22: 25892603. DOI: $10.13057 /$ biodiv/d220706.

Sivarajah S, Sandy M, Smith SM, Thomas SC. 2018. Tree cover and species composition effects on academic performance of primary school students. PLoS ONE 13 (2): e0193254. DOI: 10.1371/journal.pone.0193254. 
Speake J, Edmondson S, Nawaz H. 2013. Everyday encounters with nature: Students' perceptions and use of university campus green spaces. J Stud Res Hum Geogr 7 (1): 21-31. DOI: 10.5719/hgeo.2013.71.21.

Sundarapandian SM, PS Swamy. 2000. Forest ecosystem structure and composition along an altitudinal gradient in the Western Ghats, South India. J Trop For Sci 12 (1): 104-123.

Suratissa DM, Rathnayake US. 2016. Diversity and distribution of fauna of the Nasese Shore, Suva, Fiji, Islands with reference to existing threats to the biota. J Asia-Pac Biodivers 9 (1): 11-16. DOI 10.1016/j.japb.2015.12.002.

Susilowati A, Elfiati D, Rachmat HH, Yulita KS, Hadi AN, Kusuma YS, Batu SAL. 2020. Vegetation structure and floristic composition of tree species in the habitat of Scaphium macropodum in Gunung Leuser National Park, Sumatra, Indonesia. Biodiversitas 21 (7): 3025 3033. DOI: $10.13057 /$ biodiv/d210720.

Susilowati A, Rangkuti AB, Rachmat HH, Iswanto AH, Harahap MM, Elfiati D, Slamet B, Ginting IM. 2021. Maintaining tree biodiversity in urban communities on the University Campus. Biodiversitas 22 (5): 2839-2847. DOI: 10.13057/biodiv/d220548.

Syam. 2020. Ciri ciri pohon mahoni (Swietenia Mahagoni) di alam liar. https://www.ciriciripohon.com/2020/02/ciri-ciri-pohon-mahoni-dialam-liar.html. [4-7-2021]

Thomas A. 2011. Field guide for identifying forest tree species, Kalimantan Forests and Climate Partnership (KFCP). IndonesiaAustralia Forest Carbon Partnership, Jakarta, Indonesia.

Tian F, Liu LZ, Yang JH, Wu JJ. 2021. Vegetation greening in more than 94\% of the Yellow River Basin (YRB) region in China during the 21 st century caused jointly by warming and anthropogenic activities. Ecol Indicators 125: 107479. DOI: 10.1016/j.ecolind.2021.107479.

Tiwary A, Kumar P. 2014. Impact evaluation of green-grey infrastructure interaction on built-space integrity: An emerging perspective to urban ecosystem service. Sci Total Environ 487: 350-360. DOI 10.1016/j.scitotenv.2014.03.032.
Tudorie CAM, Planells MV, Eric GE, Arroyo R, Galiana F. 2020. Towards a greener university: Perceptions of landscape services in campus open space. Sustainability 12 (5): 6047. DOI: $10.3390 / \mathrm{su} 12156047$

UI GreenMetric. 2020a. Guideline UI Greenmetric World University Rankings 2020. University of Indonesia, Depok, Indonesia. [Indonesian]

UI GreenMetric. 2020b. Fact File 2020 UI GreenMetric World University Rankings Universitas Riau. University of Indonesia, Depok, Indonesia. [Indonesian]

Velazquez L, Munguia N, Platt A, Taddei J. 2006. Sustainable university: What can be the matter? J Cleaner Prod 14 (9-11) : 810-819. DOI: 10.1016/j.jclepro.2005.12.008.

Whittaker RH. 1975. Communities and Ecosystem. Macmillan Publishing, New York.

Wolsink M. 2016. Environmental education excursions and proximity to urban green space - Densification in a 'compact city'. Environ Educ Res 22 (7): 1049-1071. DOI: 10.1080/13504622.2015.1077504.

World Conservation Monitoring Centre. 1998. Swietenia macrophylla. The IUCN Red List of Threatened Species 1998: e.T32293A9688025. DOI: 10.2305/IUCN.UK.1998.RLTS.T32293A9688025.en. [31-10-2021]

Wulandari I, Hendrawan R, Husodo T, Megantara EM. 2018. Vegetasi structure and composition in Ciletuh Geopark, Sukabumi Indonesia. Asian J For 2 (2): 54-61. DOI: 10.13057/asianjfor/r020203.

Zhang B, Xie G, Li N, Wang S. 2015. Landscape and urban planning effect of urban green space changes on the role of rainwater runoff reduction in Beijing, China. Landsch Urban Plan J 140: 8-16. DOI: 10.1016/j.landurbplan.2015.03.014.

Zölch T, Maderspacher J, Wamsler C, Pauleit S. 2016. Urban forestry and urban greening using green infrastructure for urban climate-proofing: An evaluation of heat mitigation measures at the micro-scale. Urban For Urban Green 20: 305-316. DOI: 10.1016/j.ufug.2016.09.011. 